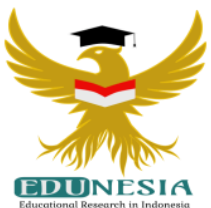

\title{
Preliminary Diagnostic Assessment in Distance Learning at SMAN 1 Pagaden
}

\author{
Mimih Sukmayanti' ${ }^{1}$ Hani Chaerunnisa ${ }^{2}$; Anwar Shidiq Santoso ${ }^{3}$ \\ ${ }^{1}$ Mathematics Education, SMAN 1 Pagaden, Indonesia \\ 2,3 Geography Education, SMAN 1 Pagaden, Indonesia \\ ${ }^{1}$ Corresponding Email: sukmayantimimih@gmail.com, Phone Number: $0898 \times x \times x \times x \times x$
}

\section{Article History:}

Received: Mar 30, 2021

Revised: Apr 30, 2021

Accepted: May 05, 2021

Online First: May 08, 2021

\section{Keywords:}

Distance learning,

Preliminary diagnostic

assessment.

\section{Kata Kunci:}

Asesmen diagnostik awal, pembelajaran jarak jauh.

\section{How to cite:}

Sukmayanti,

Chaerunnisa, $\mathrm{H}_{2}$ \& Santos A.S. (2021). Preliminary Diagnostic Assessment in Distance Learning at SMAN 1 Pagaden. Edunesia: Jurnal Ilmiah Pendidikan, 2 (2): 503513.

This is an open access article under the $C C-B Y-N C-N D$ license
Abstract: So far, distance learning still faces many obstacles in its implementation. Starting from compiling lesson plans, learning methods, to conducting evaluations. Moreover, the psychological factors of students in facing this pandemic, they are required to study at home with various kinds of challenges and obstacles. Limitations of gadgets (smartphone), internet quota to internet networks that do not reach where they live because they are in rural areas. To find a solution to this problem, a study was conducted regarding the initial conditions of SMAN 1 Pagaden students in carrying out this distance learning. By using the Miles \& Huberman analysis method, which will find interactive patterns of relationships and to get an understanding of the meaning of the obstacles faced in the distance learning process at SMAN 1 Pagaden by using non-verbal interview techniques. The questionnaire is distributed via google form which then the data obtained is used as a reference for developing distance learning strategies. Based on the results of interviews, respondents who answered that distance learning at SMAN 1 Pagaden was less effective, it was $49.8 \%$. Students hope that distance learning does not give many assignments but there is material delivery through google meet or zoom meeting. For students who are not reached by internet and gadget (smartphone) facilities, the visiting teacher model is carried out with small groups.

Abstrak: Pembelajaran jarak jauh selama ini masih menghadapi banyak kendala dalam pelaksanaannya. Mulai dari menyusun rencana pembelajaran, metode pembelajaran, hingga melakukan evaluasi. Terlebih lagi faktor psikologis siswa dalam menghadapi pandemi ini, mereka diharuskan belajar di rumah dengan berbagai macam tantangan dan hambatan. Keterbatasan gadget (hp), kuota internet sampai jaringan internet yang tidak menjangkau tempat tinggalnya karena berada di pedesaan. Untuk mencari solusi mengenai permasalahan tersebut maka dilakukan sebuah penelitian mengenai kondisi awal siswa SMAN 1 Pagaden dalam melaksanakan pembelajaran jarak jauh ini. Dengan menggunakan metode analisa Miles \& Huberman yang akan menemukan pola hubungan yang bersifat interaktif serta untuk memperoleh pemaham makna mengenai kendala yang dihadapi pada proses pembelajaran jarak jauh di SMAN 1 Pagaden dengan menggunakan teknik wawancara non verbal. Angket disebar melalui google form yang kemudian data yang diperoleh dijadikan rujukan untuk menyusun strategi pembelajaran jarak jauh. Berdasarkan hasil wawancara, responden yang menjawab pembelajaran jarak jauh di SMAN 1 Pagaden kurang efektif berjumlah 49,8\%. Siswa berharap bahwa pembelajaran jarak jauh tidak banyak memberikan tugas tetapi ada penyampaian materi melalui google meet atau zoom meeting. Bagi siswa yang tidak terjangkau fasilitas internet dan gadget (hp) dilakukan model guru kunjung dengan kelompok kecil. 


\section{A. Introduction}

The COVID-19 pandemic has spread to almost various parts of the world. Many things have changed due to the spread of this pandemic, such as economic activity, offices, worship practices, and interaction patterns. This also has an impact on education systems around the world, learning which is usually face-to-face is now done through distance learning to reduce the risk of transmission from COVID-19. In a study (Pradana et al, 2020) published in the Indonesian Health Policy Journal, it is stated that children are an age category vulnerable to COVID-19. The research reveals that "in the pandemic phase there are several vulnerable age groups, namely; children, pregnant women, and the elderly are among the groups that experience the worst impacts. What are the prevention efforts, the obstacles that might occur in implementing prevention efforts, and what modifications can vulnerable groups make to support social distancing efforts? This research is a logical reference in implementing long-distance chasing as an effort to prevent the transmission of COVID-19.

On the other side, this online model of distance learning is considered less effective when compared to face-to-face learning. This is the same as research conducted by Mulatsih (2020) which found obstacles in online learning at SMA Negeri 1 Banguntapan. "Students find it difficult to understand the material conveyed through the WhatsApp group and there are still those who do not have good internet coverage where they live".

There are several factors that need to be considered in implementing the online model of distance learning, such as the ownership of a gadget (smartphone), internet signal, internet quota, and learning methods that are in accordance with the ability of teachers and students to carry out distance learning. In a study, there was a tendency that distance learning was less effective due to learning patterns that limited the discussion space between educators and students, this was revealed in a study conducted by Mulyadi (2020) at SMK Negeri 3 Yogyakarta. "The obstacle faced in online learning is in the form of a low signal network so that the task has to be submitted repeatedly or even delayed".

As an effort to optimize distance learning at SMAN 1 Pagaden, a study entitled "preliminary diagnostic assessment in distance learning at SMAN 1 Pagaden" was conducted to examine the readiness of students, parents, schools, and teachers in implementing distance learning. This study will examine the cognitive and non-cognitive conditions of students so that distance learning can be applied properly.

\section{B. Method}

This research uses descriptive qualitative, namely research methods based on the philosophy of post positivism, qualitative research is used to examine the conditions of natural objects. In this case, the research will focus on matters relating to the readiness of SMAN 1 Pagaden in carrying out distance learning using survey techniques to 613 respondents. The questionnaire is distributed through the Wa Group using google form. The survey was conducted on Class X and XI students, totaling 613 students. From the questions "yes or no" regarding the effectiveness of distance learning presented in google form and the results will be analyzed by means of data reduction, data presentation, drawing conclusions / verification which will give the possibility of drawing conclusions and taking action. The research was conducted at the beginning of the learning process, starting from July to October 2020. 


\section{Result and Discussion}

The research begins by compiling the relevant questions for the diagnostic of the initial conditions of distance learning at SMAN 1 Pagaden. Then the questionnaire was distributed through the WA Group using the google form. The study was divided into three stages, namely examining the readiness of students to carry out distance learning, the psychology of students in facing the pandemic, and the readiness of teachers in carrying out distance learning.

\section{Readiness of Students in Distance Learning}

To carry out distance learning, students and teachers are required to have devices to support remote learning such as gadgets (smartphones) based on Android or IOS and laptops.

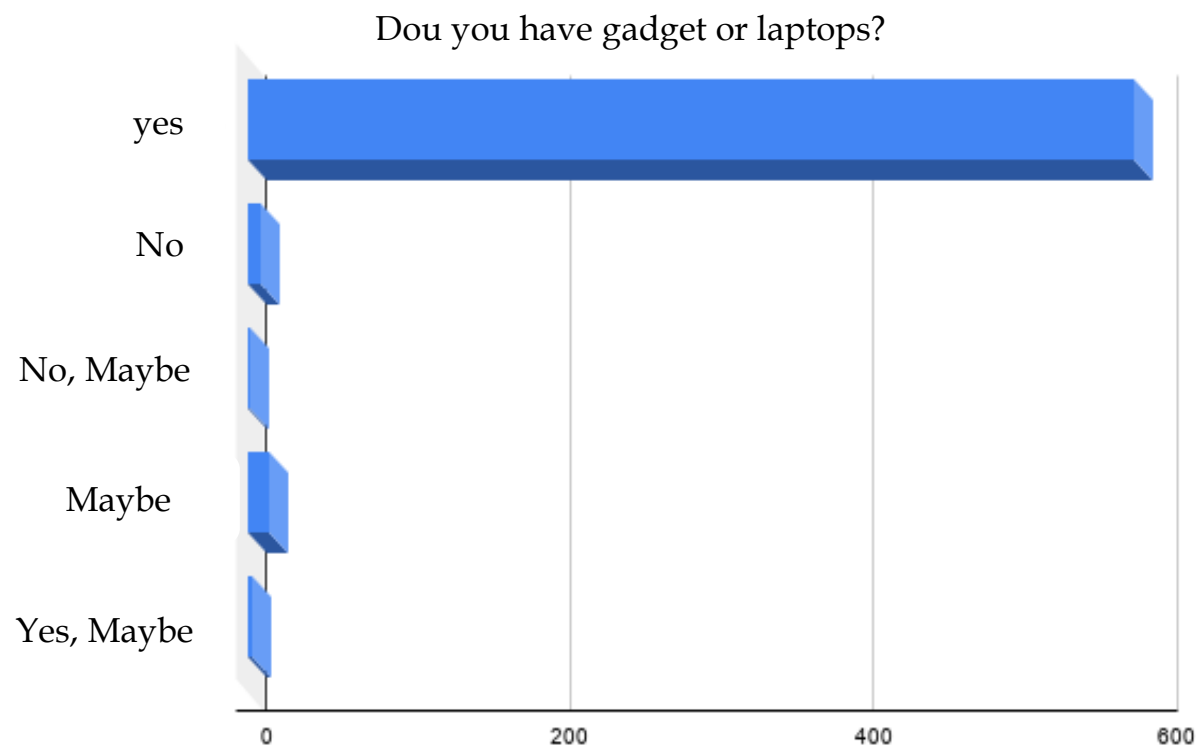

Figure 1. Students who have gadgets (smartphone) or laptops

Students who have facilities that support distance learning are around 95.9\%, while those who do not have at all are $1.8 \%$ and those who have gadgets but are used by several other family members are $3.1 \%$. This condition is also experienced by other schools that carry out distance learning, such as in a study conducted by Anugrahana (2020) which found that "online learning in its implementation has obstacles, among others; (1), There are some children who do not have devices. (2) There are students who have smartphones but are constrained by an internet connection, so they are hampered in sending assignments because of signal difficulties. (3) Some students do not have their own smartphone, so they have to borrow them. (4) Parents have smartphone but parents work all day outside the house so that parents can only accompany them at night".

Although almost all students at SMAN 1 Pagaden have supporting facilities for carrying out distance learning, there are still around $4.1 \%$ students who do not have these facilities so that schools and teachers have to do learning using offline and visiting models.

\section{Internet Signal Affordability}

Carrying out distance learning is not enough to have a gadget (smartphone) or laptop but also needs to be supported by a high internet signal. Most of the constraints are 
related to the internet signal in the villages which cannot be reached properly. This condition should also become a discussion material to determine a distance learning model that can be applied at SMAN 1 Pagaden.

Is your internet provider's signal good?

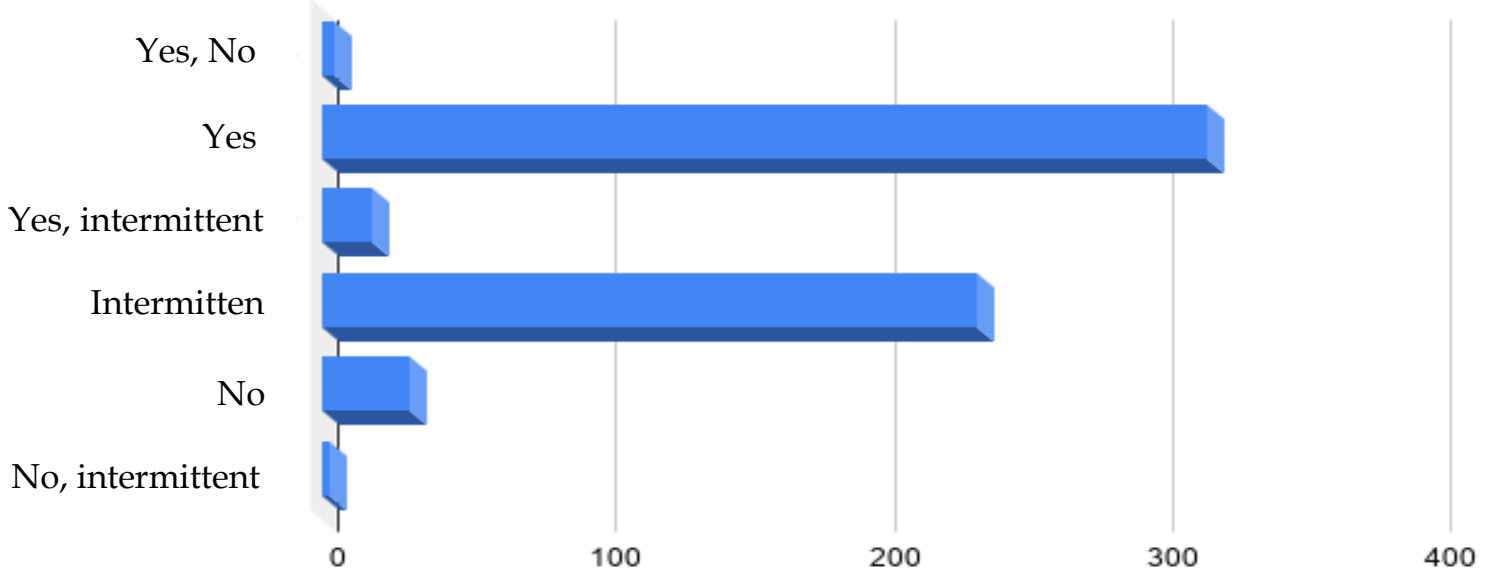

Figure 2. Internet signal condition

Seeing the signal conditions in the student residences, there are still many who have low internet access. Approximately $6.5 \%$ of student residences with low internet signal conditions and around $41.9 \%$ of student residences have intermittent internet access. Whereas those with good internet coverage are around 55.8\%, from this data that distance learning at SMAN 1 Pagaden cannot be done with a zoom meeting model, google meet, cisco webex, or other video conference applications because there are still many students who have access. Internet is not good and it is feared that it will interfere with the continuity of learning when using video conferencing applications. The recommended distance learning at SMAN 1 Pagaden is to use google classroom, Wa Group, offline, or learning applications that do not use video conferencing. The problem of internet signal affordability has also been raised in a journal written by Sadikin \& Hamidah (2020) "online learning is not properly supervised during the learning process. Low internet signal and high quota fees are challenges for online learning".

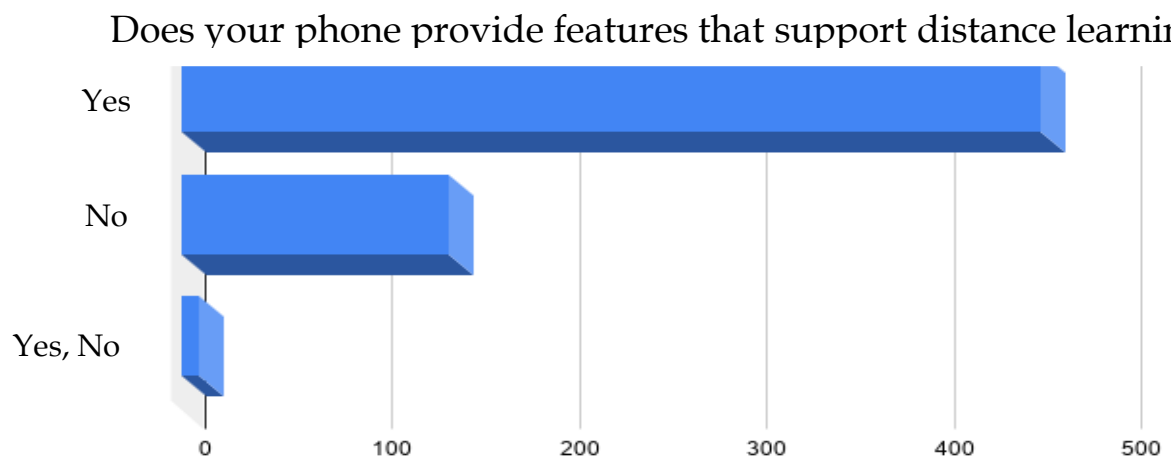

Figure 3. Student gadget (smartphone) condition

About $25 \%$ of students who cannot access learning applications that support online learning are due to the condition of the gadget (smartphone) which has low Android 
specifications as well as small memory storage space so that they can no longer download other applications. However, about $75 \%$ of students already have a gadget (smartphone) with good capacity. As a solution, when learning using video conferencing, the closest student can join students who have gadgets that can do video conferencing, but the number of students who take video conferencing with their friends is only allowed up to a maximum of 3 students.

\section{Effectiveness of Distance Learning}

For something new in the learning method, distance learning still needs to be addressed in its technical implementation so that distance learning can be more effective. The effectiveness of distance learning is considered less effective when compared to face-toface learning, this was stated in the study Abidin et al (2020) that $53 \%$ of respondents felt they did not understand online learning material. Meanwhile, $47 \%$ of respondents found it easy to understand learning materials conducted online".

Has the distance learning been implemented been effective?

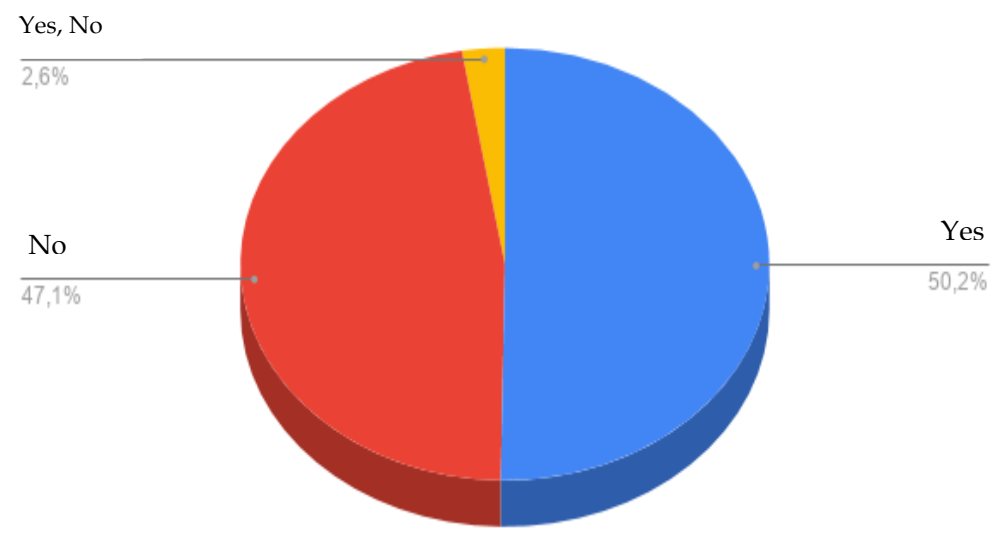

Figure 4. The effectiveness of distance learning at SMAN 1 Pagaden

The results of the google form that were distributed to students of SMAN 1 Pagaden, from 613 respondents stated that the distance learning carried out at SMAN 1 Pagaden who answered not yet effective was $49.8 \%$ and those who answered distance learning were effective amounting to $50.2 \%$.

A similar condition is also experienced by most students of SMA Negeri 8 Mataram, as revealed in a study by Susilawati (2020) which states that "online learning conducted at SMA Negeri 8 Mataram considers online learning ineffective, this can be seen the participation of Class X Mia 1 and Class X Mia 2 students towards online learning is still low". To increase the effectiveness of distance learning at SMAN 1 Pagaden, all levels of teachers conduct discussions and coordination to develop strategic steps for learning designs that are in accordance with the conditions of students at SMAN 1 Pagaden.

\section{Distance Learning Based on Student Needs}

In carrying out the $5 \mathrm{M}$ principle as a form of initial diagnosis, discussions are held with students in order to humanize humans. The discussion room was carried out via google form which students answered directly about distance learning in accordance with the expectations of students of SMAN 1 Pagaden. There are several things that must be 
considered in the principle of distance learning (Nindiati, 2020), "namely; assignments, time, and understanding of students and their limitations".

The complaints experienced by most students in distance learning are piling up tasks, so that each teacher is expected to discuss giving assignments alternately to the same class. The most important thing that must be of concern in distance learning is students 'understanding of the material and students' understanding of using learning devices and applications. This expression is very relevant to the research conducted by Rifqi (2020) "in carrying out distance learning one should pay attention to internal collaboration between one field and another and external relations with other higher education institutions that hold online education programs. So that the assignment does not happen at the same time".

what kind of distance learning you expect?

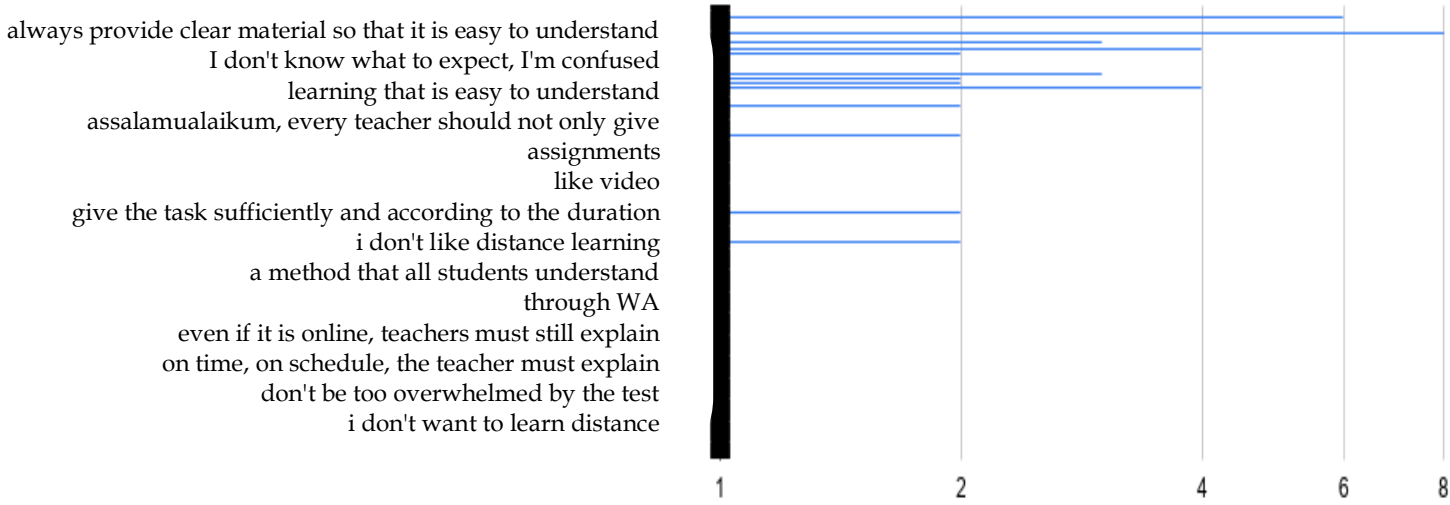

Figure 5. Distance learning based on student needs at SMAN 1 Pagaden

About $1 \%$ of respondents stated that students do not want distance learning, they want learning to be done face-to-face. 1,8\% of respondents hope that distance learning does not provide many assignments but there is material delivery that is delivered through the google classroom or zoom meeting application. From the results of this survey then it became input for SMAN 1 Pagaden teachers who were delivered through the Deputy Principal for Curriculum Affairs not to assign too many assignments to students, even if there were assignments given students hoped that the teacher concerned had to explain the material first. delivered via google classroom or zoom meeting.

\section{Non-Cognitive Diagnostic Assessment}

Non-cognitive aspects of diagnostic assessments are used to determine distance learning strategies and technologies. (Gustafson and Branch in Muhammad, 2018) "in developing media and learning technology are divided into three categories, namely: (1) classroom-oriented models, (2) product-oriented models, and (3) a system-oriented model. (Muhammad, 2018) "Each model has advantages and disadvantages and can be directed according to the type of learning product being developed. For example, if developing a system of distance learning, blended learning or e-learning, the appropriate model is the Dick and Carrey model. The Dick and Carrey model (Aji, 2016) "in the development of a subject it is intended that: (a) at the beginning of the learning process, students or students can know and be able to do things related to the material at the end of the lesson, (b) the existence of linkages between each component, especially the learning strategy and the desired learning outcomes, (c) implementing the steps that need to be taken in planning the 
learning design". Furthermore, things that need to be considered in choosing learning strategies are the readiness of students, the ability of teachers, and the availability of learning resources.

In the preparation stage of the non-cognitive diagnostic assessment, there are several things that must be prepared by the teacher, namely making aids that describe students' emotions. Then add the question what are you feeling? and how do you feel while studying at home?

The next step is to make a list of key questions regarding student activities, such as 1) What were your activities while studying at home ?; 2) The most pleasurable and unpleasant things ?; 3) What are your hopes ?. In the implementation stage students are asked to express their feelings while studying at home and explain their activities through storytelling, drawing, and writing.

Diagnostic assessment is needed, considering that learning activities at home are very vulnerable to dropping out of school, the learning achievement gap is widening, the impact of stress on students, and learning loss.

COVID-19 not only threatens the health sector but also threatens economic activities which can lead to higher unemployment. (Maryanti et al, 2020) "The weakening of the economic sector can have a direct impact on the dropout rate. So that the government is expected to be able to provide subsidized assistance for small and medium-sized economic people who are affected by COVID-19".

\section{What do you feel right now}

Why is an preliminary diagnostic assessment necessary? Namely, to determine the psychological condition of students by asking questions, such as those written in a pocket book (Setiawan, 2018) "Who are our students? What answer did you find? our students are people who have an obligation to go to class from morning to evening. Our students are the ones who have to sit quietly listening to the teacher speak. Our students are people whose presence makes the role of the teacher meaningful. Our students are people who are needed to attend so that our institution can be called a school. Sometimes our students' behavior can offend our profession as teachers. Students are people who need to learn. The student is a person who must respect the teacher. Students are people who have to study diligently so that their test scores don't interfere with our existence as teachers. Some of our students are people from the poor, so their abilities are limited. Some of our students are people from the rich, so their attitudes are spoiled. Is there your answer in one of the alternative answers above? or you have a different answer"?

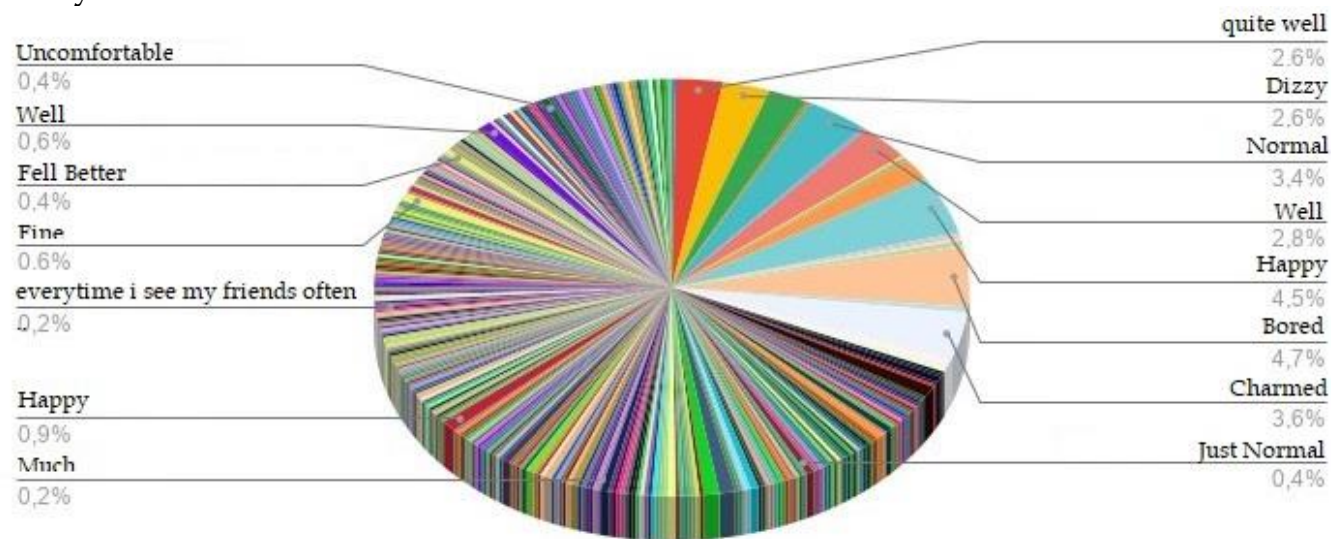

Figure 6. What students of SMAN 1 Pagaden feel when learning distance. 
Various expressions felt by students of SMAN 1 Pagaden in carrying out distance learning. This unusual situation resulted in students having to study at home using online, offline, or integrated learning models. When carrying out distance learning students experience various expressions, such as students who feel bored with learning with distance learning amounting to $0.4 \%$, as many as $6.4 \%$ of respondents said they felt fine during this pandemic, around $9 \%$ of respondents stated happy in the face of a pandemic situation, and those who expressed boredom with a pandemic situation that caused learning to be done remotely amounted to $8.1 \%$.

\section{How to Feel When Studying at Home}

The atmosphere of studying at home and learning face-to-face at school will of course provide a different experience. The learning atmosphere in the classroom students can interact directly with the teacher and their friends, students can gather and joke when learning is carried out at school.

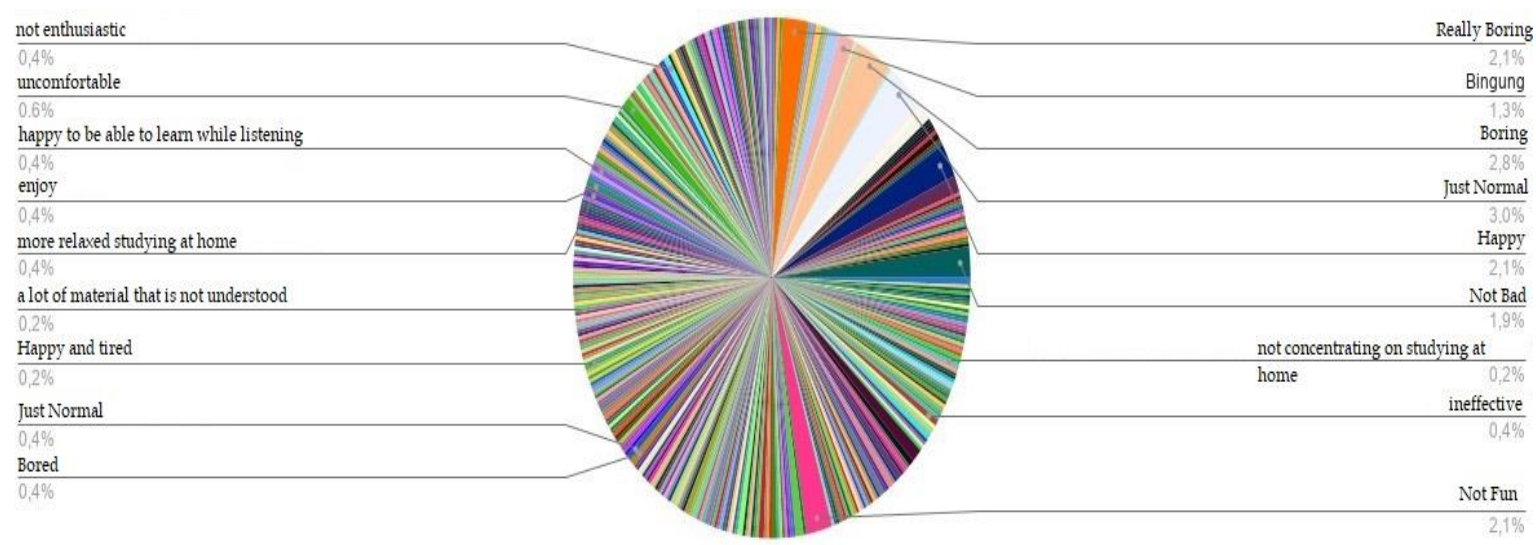

Figure 7. Student response of SMAN 1 Pagaden when studying at home

From the graph above it can be seen that there are students who feel confused about this pandemic situation, students who feel confused based on the graph above are $1.3 \%$. Students who stated that they were bored while studying at home were $5.5 \%$, for respondents who said they were uncomfortable were $8.3 \%$, and various other experiments such as; taken casually, a lot of material that is not understood, and taken casually. In this case the majority of respondents expect to learn face-to-face immediately by implementing strict health protocols. The same anxiety occurs with other students as in research (Oktawirawan, 2020) "Various attempts have been made by the students to overcome the anxiety they are experiencing. For example, students try to study independently, do the best they can, discuss with friends and teachers in order to be able to understand the material well. Students also try to be patient, encourage themselves, and pray for strength in undergoing online learning. Other activities undertaken to reduce anxiety are sleeping, listening to music, watching television or movies, playing games, eating, drinking coffee and exercising". 


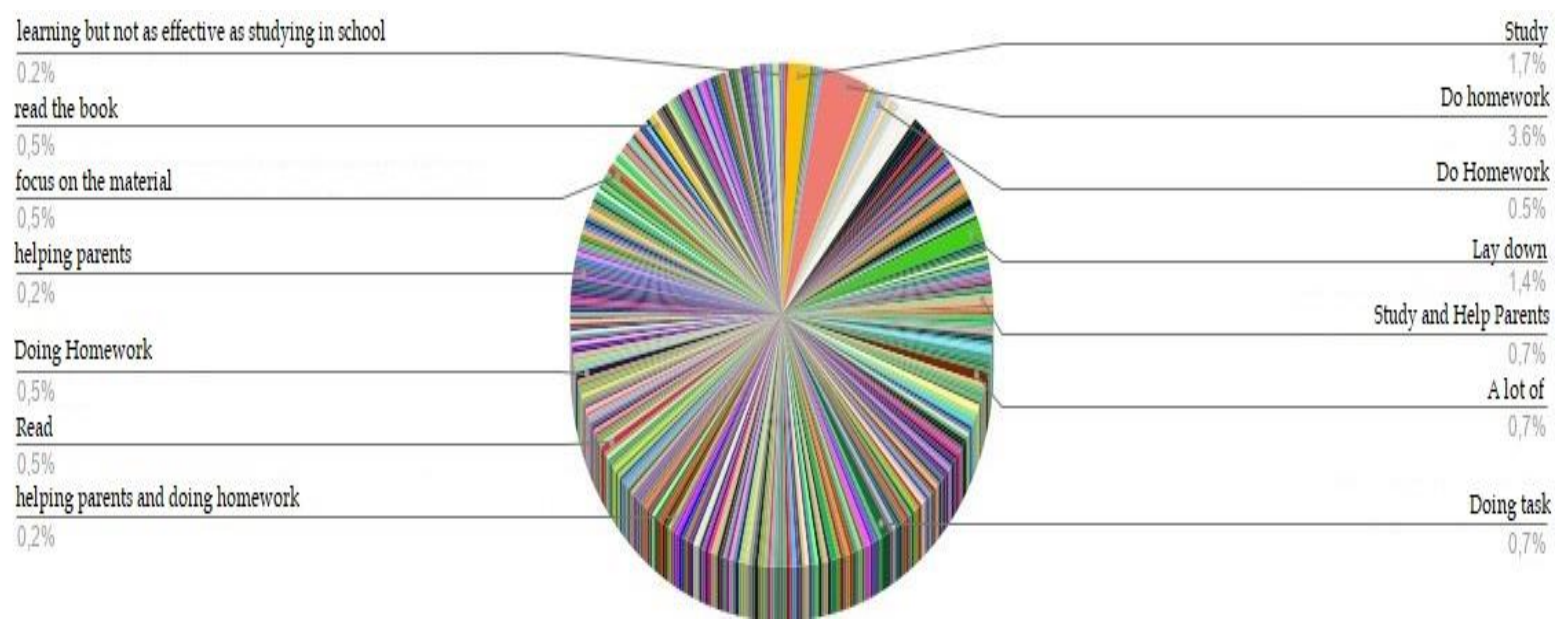

Figure 8. What are the students' activities while studying at home.

As much as $2.9 \%$ of respondents said that while studying at home the activities of students were studying and reading, students who studied and helped their parents at home amounted to $1.9 \%$, and as much as $1.6 \%$ of the respondents stated that while studying at home they only played. Looking at the data from the graph shows that during this pandemic period students in studying at home experienced many psychological situations. So it is expected that the Counseling Guidance and teacher class can play an active role in providing motivation to learn. Of course the decreased student motivation is not only experienced by students of SMAN 1 Pagaden but this situation also occurs in various places, as described in the study (Cahyani et al, 2020) "The condition of the online learning environment requires that students to study in their own homes, teachers cannot assist and educate students directly so that teachers cannot take actions such as giving gifts, praising, reprimanding, punishing, and giving advice. Whereas the teacher's actions can strengthen students' intrinsic motivation.

Descriptive data shows that out of 344 students $52.6 \%$ of them admit that their enthusiasm for learning has decreased during online learning. The conditions for learning at home are certainly different from those in the classroom. At home, students must be able to do learning independently and maintain the quality of their learning so that what learning material can be understood effectively.

\section{Conclusion}

Distance learning which is carried out at SMAN 1 Pagaden, Subang Regency, is considered ineffective, respondents who stated that distance learning is quite effective is only $49.8 \%$. Students expect the learning to be carried out face-to-face by applying very strict health protocols.

For students who experience problems in carrying out distance learning such as not having gadgets, kouta, low internet signal. Provided guidance and material through homevisit activities with a small group outdoor class model.

Teaching and learning activities are usually carried out face-to-face, but during this pandemic, learning is carried out by distance learning. This unusual concept requires a lot of habituation for both teachers and students. For teachers, it is advisable to participate in many webinar activities regarding the implementation of distance learning so that they have 
a lot of understanding and strategies for implementing distance learning which are expected to have an impact on student learning motivation during this pandemic.

\section{References}

Abidin, Z., Hudaya, A., \& Anjani, D. (2020). Efektivitas Pembelajaran Jarak Jauh Pada Masa Pandemi Covid-19. Research and Development Journal of Education. Vol 1, No 1, hal 131146, 14/10/2020. Diakses dari https://journal.lppmunindra.ac.id/index.php/RDJE. (diunduh 20 Nopember 2020).

Aji, W.N. (2016). Model Pembelajaran Dick And Carrey Dalam Pembelajaran Bahasa Dan Sastra Indonesia. Kajian Linguistik dan Sastra. Vol 1, No 2, hal 119-126 Diakses dari http://journals.ums.ac.id/index.php/KLS/article/viewFile/3631/2307. (diunduh 22 Nopember 2020).

Anggito, A., \& Setiawan, J. (2018). Penelitain Kualitatif. Sukabumi: CV. Jejak.

Anugrahana, A. (2020). Hambatan, Solusi Dan Harapan: Pembelajaran Daring Selama Masa Pandemi Covid-19 Oleh Guru Sekolah Dasar. Scholaria: Jurnal Pendidikan dan Kebudayaan. Vol 10, No 3, hal 282-289, 28/11/2020, Diakses dari https://ejournal.uksw.edu/scholaria/article/view/4033/1527.

Cahyani, A., Listiana, I.D., \& Larasati, S.P.D. (2020). Motivasi Belajar Siswa SMA pada Pembelajaran Daring di Masa Pandemi Covid-19. IQ (Ilmu Al-qur'an): Jurnal Pendidikan Islam. Vol 3, No 1, hal 123-140, 31/07/2020, Diakses dari https://doi.org/10.37542/iq.v3i01.57 (diunduh 15 Nopember 2020).

Harfiyanto, D., Utomo, C.B., \& Budi, T. (2015). Pola Interaksi Sosial Siswa Pengguna Gadget Di SMAN 1 Semarang. Journal of Educational Social Studies. Vol 4, No 1, hal 1-5, 22/08/2015, Diakses dari https://journal.unnes.ac.id/sju/index.php/jess/article/view/6859. (diunduh 8 Agustus 2020).

Maryanti, S., Netrawati, I.G.A.O., \& Nuada, I.W. (2020). Pandemi COVID-19 Dan Implikasinya Pada Perekonomian NTB. MEDIA BINA ILMIAH. Vol 14, No 11, hal 3497-3508 Diakses dari https://doi.org/10.33758/mbi.v14i10.573 (diunduh 21 Nopember 2020).

Mulatsih, B. (2020). Penerapan Aplikasi Google Classroom, Google Form, dan Quizizz Dalam Pembelajaran Kimia Di Masa Pandemi COVID-19. Ideguru: Jurnal Karya Ilmiah Guru. Vol 5, No 1, hal 16-26, Diakses dari https://doi.org/10.51169/ideguru.v5i1.129 (diunduh 01 Mei 2021).

Mulyadi, E. (2020). Pembelajaran Daring Fisika Melalui WhatsApp, Google Form, dan Email Dalam Capaian Presensi Aktif Dan Hasil Belajar Peserta Didik. Ideguru: Jurnal Karya Ilmiah Guru. Vol 5, No 1, hal 34-41, Diakses dari https://doi.org/10.51169/ideguru.v5i1.156. (diunduh 01 Mei 2021). 
Nindiati, D.S. (2020). Pengelolaan Pembelajaran Jarak Jauh Yang Memandirikan Siswa Dan Implikasinya Pada Pelayanan Pendidikan. JOEAI: Journal of Education and Instruction. Vol 3, No 1, hal 14-20, 25/06/2020 Diakses dari https://doi.org/10.31539/joeai.v3i1.1243. (diunduh 20 Nopember 2020).

Oktawirawan, D.H. (2020). Faktor Pemicu Kecemasan Siswa dalam Melakukan Pembelajaran Daring di Masa Pandemi Covid-19. Jurnal Ilmiah Universitas Batanghari Jambi. Vol 20, No 2, hal 541-544, Diakses dari http://dx.doi.org/10.33087/jiubj.v20i2.932. (diunduh 15 Nopember 2020).

Pradana, A.A., Casman., \& Nur'aini. (2020). Pengaruh Kebijakan Social Distancing Pada Wabah COVID-19 Terhadap Kelompok Rentan Di Indonesia. Jurnal Kebijakan Kesehatan Indonesia: JKKI. Vol 9, No 2, hal 61-67, 22/07/2020, Diakses dari https://doi.org/10.22146/jkki.55575. (diunduh 8 Agustus 2020).

Rifqi, A. (2020). Implementasi Total Quality Management Pada Pembelajaran Jarak Jauh. AlTanzim: Jurnal Manajemen Pendidikan Islam. Vol 2, No 2, hal 167-176, Diakses dari https://doi.org/10.33650/al-tanzim.v2i2.398 (diunduh 20 Nopember 2020).

Sadikin, A., \& Hamidah, A. (2020). Pembelajaran Daring di Tengah Wabah Covid-19. Biodik. Vol 6, No 2, hal 214-224, 30/06/2020, Diakses dari https://doi.org/10.22437/bio.v6i2.9759. (diunduh 2 September 2020).

Setiawan, B. (2018). Siapakah Murid Kita. Surat Kabar Guru Belajar, Edisi Kesatu, Tahun Ketiga, hal 4-9. (diunduh 29 Oktober 2020).

Susilawati, N.N.S. (2020). Efektifitas Pembelajaran Virtual Daring Pendidikan Agama Hindu Siswa Kelas X Mia 1 \& X Mia 2 Pada Masa Pandemi Covid -19 di SMA Negeri 8 Mataram. Cetta: Jurnal Ilmu Pendidikan,3(3a-1). Diakses dari https://jayapanguspress.penerbit.org/index.php/cetta/article/view/1006 (diunduh 01 Mei 2021).

Yaumi, M. (2018). Media Dan Teknologi Pembelajaran. Jakarta: Penerbit Prenadamedia. 